\title{
Questionnaire choice affects the prevalence of recommended physical activity: an online survey comparing four measuring instruments within the same sample
}

\author{
Gerrit Stassen ${ }^{1 *}$ D, Kevin Rudolf ${ }^{2}$, Madeleine Gernert ${ }^{1}$, Ansgar Thiel ${ }^{3,4}$ and Andrea Schaller ${ }^{1}$
}

\begin{abstract}
Background: Since prevalence estimates of recommended physical activity (PA) considerably vary between different surveys, prevalence might be crucially affected by the choice of measuring instrument. The aim of the present study is to compare the results of four PA questionnaires regarding the current moderate- and vigorousintensity aerobic PA (MVPA) recommendations of the World Health Organization.

Methods: Within an online survey, participants answered the German Health Interview and Examination Survey for Adults (DEGS), the European Health Interview Survey PA Questionnaire (EHIS), the Eurobarometer (EURO), and a single-item measure (SIM). Weekly volume of MVPA was compared via a Friedman test and the prevalence of participants achieving the WHO's MVPA recommendation via Cochran's Q. Agreement between all questionnaire pairs was evaluated via Kappa statistics.

Results: One hundred seventy-six participants were included in the analyses (70.5\% female, mean age: 33.1 years $(S D=12.2)$ ). Between the four questionnaires, the weekly volume of MVPA statistically significant differed (SIM: MED= 90.0 (MIN=0.0, MAX=210.0), DEGS: MED=120.0 ( $M I N=0.0, M A X=420.0), E H I S: M E D=240.0$ (MIN=0.0, MAX=1395.0), EURO: MED $=510.0$ ( $\mathrm{MIN}=0.0, \mathrm{MAX}=2430.0), p<.001$, all pairwise comparisons $p<.01)$, as well as the prevalence of participants achieving the MVPA recommendations (SIM 31.3\% (95\% Cl 24.5-38.7), DEGS 43.2\% (95\% Cl 35.8-50.8), EHIS 67.0\% (95\% Cl 59.6-73.9), EURO 87.5\% (95\% Cl 81.7-92.0), $p<.001$ ), except between SIM and DEGS ( $p=.067)$. Agreement was weak between all questionnaire pairs (all $k<0.60$ ).

Conclusions: Questionnaire choice crucially affects the resulting MVPA data and hence the prevalence of achieving recommended PA levels within the same sample. Therefore, for PA surveillance, standardised survey and analysis methods and efforts to harmonise monitoring systems are needed, since whether recommended levels of PA are achieved should not be determined by the choice of one measuring instrument or another.
\end{abstract}

Keywords: Physical activity, Recommendations, Surveillance, Assessment, Methodology, Epidemiology

\footnotetext{
* Correspondence: g.stassen@dshs-koeln.de

'Working Group Physical Activity-Related Prevention Research, Institute of Movement Therapy and Movement-Oriented Prevention and Rehabilitation German Sport University Cologne, Am Sportpark Müngersdorf 6, 50933 Cologne, Germany

Full list of author information is available at the end of the article
}

(c) The Author(s). 2020, corrected publication 2021. Open Access This article is licensed under a Creative Commons Attribution 4.0 International License, which permits use, sharing, adaptation, distribution and reproduction in any medium or format, as long as you give appropriate credit to the original author(s) and the source, provide a link to the Creative Commons licence, and indicate if changes were made. The images or other third party material in this article are included in the article's Creative Commons licence, unless indicated otherwise in a credit line to the material. If material is not included in the article's Creative Commons licence and your intended use is not permitted by statutory regulation or exceeds the permitted use, you will need to obtain permission directly from the copyright holder. To view a copy of this licence, visit http://creativecommons.org/ licenses/by/4.0/. The Creative Commons Public Domain Dedication waiver (http://creativecommons.org/publicdomain/zero/1. 0/) applies to the data made available in this article, unless otherwise stated in a credit line to the data. 


\section{Background}

The multiple positive effects of physical activity (PA) on health are well established [1-4]. At the same time, inactivity has a major negative health effect worldwide [5] and insufficient PA is one of the leading risk factors of global mortality [6], as well as being responsible for a substantial economic burden [7], thus underlining the importance of populationwide PA surveillance based on accurately-collected data.

The global recommendations on PA for health of the World Health Organization (WHO) for adults aged 1864 years comprise aerobic PA for at least $150 \mathrm{~min}$ at moderate intensity or at least $75 \mathrm{~min}$ at vigorous intensity throughout the week, or an equivalent combination of moderate- and vigorous-intensity activity (MVPA) $[8,9]$. In addition, muscle-strengthening activities and exercises (MSE) involving major muscle groups should be performed on two or more days a week. Comparable recommendations can be found in several national guidelines, e.g. for the United Kingdom [10], the United States [11], Australia [12], and Germany [13].

Worldwide, it has been estimated in recent years that about $30 \%$ of adults are physically inactive [14, 15] and the current target of the $\mathrm{WHO}$ is a $15 \%$ relative reduction in the global prevalence of insufficient PA by 2030 [16]. However, cross-country comparisons show large differences in the percentage of people achieving the recommendations for PA. Reviews report prevalence estimates ranging from $7 \%$ up to $96 \%[17,18]$. Within a single country, Macniven et al. report prevalence ranging from 18 to $92 \%$ depending on the respective survey [18].

Comparable ranges can also be found in representative German surveys. In two surveys by the Robert Koch Institute (RKI), prevalence of 20\% [19] (survey period: November 2008-December 2011, $n=7988$ ) and 45\% [20] (survey period: November 2014 - July 2015, $n=22959$ ) is reported. Another nationwide study again reports a prevalence of 53\% [21] (survey period: March - April 2012, $n=2248$ ), while in the Eurobarometer survey $84 \%$ of the German sub-sample reaches the MVPA recommendations [22] (survey period: November - December 2013). Since the studies listed above state that the samples were weighted according to the structure of the German population, and given that they all refer to current recommendations regarding the prevalence of recommended MVPA, it could be assumed that the considerable differences in prevalence estimates may be due to variations in the measurement and analysis of the recommended MVPA, and not necessarily differing PA behaviour among the populations surveyed. The studies used different self-report measures, which raises the question of how the choice of questionnaire alone could affect the prevalence of recommended MVPA.

Already two decades ago, Sarkin et al. [23] examined the results of three questionnaires in terms of achieving two PA guidelines, finding that within the same sample at the same measurement point, the proportion of those meeting the 1990 American College of Sports Medicine (ACSM) fitness guidelines [24] was $32-59 \%$ and the proportion of those meeting the 1995 Centers for Disease Control and Prevention (CDC)/ACSM health-related guidelines [25] was 4-70\%, respectively, depending on the chosen questionnaire. In a study by SteeneJohannessen et al. [26], similarly wide ranges can be observed in a comparison of three questionnaires within the same sample, as the prevalence of recommended MVPA ( $\geq 150 \mathrm{~min} /$ week) was between 40 and $88 \%$.

In order to compare prevalence studies conducted with self-report measures regarding current PA recommendations, it is essential that the prevalence is unaffected by the choice of the instrument. However, if the prevalence of recommended PA depends on the chosen questionnaire, this would call into question PA surveillance and the comparability of surveys.

But since it does not seem certain that different questionnaires measuring the same behaviour necessarily lead to the same or comparable prevalence, the present study aims to compare the results of four PA questionnaires, that were recently used in national or international surveys and/or measure recommended PA with a minimum number of items, within one sample in terms of achieving the WHO's current MVPA recommendations for adults.

\section{Methods}

Study design

The online survey was created via the software EFS Survey (Questback GmbH, Cologne, Germany) and pilot tested prior to its dissemination. The survey period lasted for 1 month (31st October - 30th November 2019). The study sample was recruited via the website, the official Facebook account, and the official Twitter account of the German Sport University Cologne, as wells as SurveyCircle, a web portal for the acquisition of study participants, and associated Twitter accounts. Participants were invited to answer an online survey regarding the measurement of PA and the comparison of questionnaires. Prior to the start of the survey, participants were informed about anonymity and that the data would be evaluated for scientific purposes. Participants received no financial incentives.

\section{Measures}

During the online survey, each participant answered four PA questionnaires (German versions) in one session one after the other, with the survey software randomising the order to balance order effects: 
- the PA-related questions of the German Health Interview and Examination Survey for Adults (DEGS1) [19, 27] (DEGS);

- the European Health Interview Survey-Physical Activity Questionnaire [28] (EHIS);

- the PA-related questions of the Eurobarometer survey, wave 80.2 [29] (EURO); and

- a single-item measure (SIM) (self-translation of a PA screening tool by Milton et al. [30]).

All questionnaires have recently been used in population-wide surveys and/or - according to corresponding publications - in case of the SIM provide a short self-report option to determine whether the respondents achieve current MVPA recommendations ( $\geq 150 \mathrm{~min} /$ week) (Table 1).

The DEGS comprises two items. The first asks about the number of days in an average week during the last 3 months with PA on which the respondent had started sweating or found themselves of breath [19]. The wording was based on the CDC recommendations [25] to raise the respondents' awareness of the recommended minimum intensity. The second item asks about the daily duration of PA on each of these days with the following options: less than $10 \mathrm{~min}, 10$ to less than $30 \mathrm{~min}$, 30 to less than $60 \mathrm{~min}$, more than $60 \mathrm{~min}$. In the corresponding RKI publication, no information on reliability and validity is given, but "it is possible to approximately estimate the proportion of those who fulfil the WHO recommendation of $2.5 \mathrm{~h} /$ week." [19]. Permission for the scientific use of this measuring instrument was obtained in advance from the RKI.

The EHIS comprises eight items regarding PA in different domains (workplace, transport, leisure time, muscle-strengthening) during a typical week "and [it] allows to estimate the health-enhancing PA recommendation compliance" [28]. First, a description of the time spent on work is asked for. The next four items (transport) ask about the number of days per week on which the respondet walked or cycled for at least $10 \mathrm{~min}$ and the respective duration (response options: "10-29 minutes per day", "30-59 minutes per day", "1 hour to less than 2 hours per day", " 2 hours to less than 3 hours per day", " 3 hours or more per day"). The next two items ask first about the number of days per week with at least $10 \mathrm{~min}$ of sports, fitness or recreational (leisure) PA (excluding work and transport), showing at least a slight increase in breathing or heart rate, and second about the total weekly time (being expressed in hours and minutes per week). Test-retest reliability for aerobic healthenhancing PA has a correlation coefficient of 0.43 and concurrent validity coefficients with self-report and objective criterion measures are 0.41-0.64 [31]. In addition. The final item asks about the number of days with activities specifically designed to strengthen muscles (resistance training or strength exercises) [28], whereby it is the only one among the questionnaires included in the present study to survey the whole WHO PA recommendations. The measuring instrument was taken from the questionnaire of the German Health Update 2014/ 2015 - European Health Interview Survey of the RKI, which may be reused for scientific purposes [32].

The EURO comprises six items that ask about PA via the number of days of vigorous activity, moderate activity (excluding walking), and walking for at least $10 \mathrm{~min}$ in the last 7 days [29] and the respective daily duration (response options: "30 min or less", "31 to $60 \mathrm{~min}$ ", "61 to 90 min", "91 to 120 min", "more than 120 min", "never do [type of activity]", "don't know") "in order to assess the levels of physical activity ( ...) according to the WHO's recommendations" [22]. The items are slightly modified items of the International Physical Activity Questionnaire [22], which shows acceptable reliability [33, 34] but low concurrent validity in terms of correlations with objective measurement methods [33, 35]. The measuring instrument is freely available online [29].

The SIM uses a past-week recall period asking about the number of days with at least $30 \mathrm{~min}$ of PA with an intensity that raises the breathing rate, including sport, exercise, walking, and cycling for recreation, but excluding housework and work-related PA. For the present study, the German version [36] of the single-item measure by Milton et al. [30] - whose wording refers to the recommendations of $30 \mathrm{~min}$ of moderate intensity activity on five or more days of the week [37] - was slightly rephrased. The underlying measure shows strong reproducibility (test-retest correlation coefficient 0.72 ) and modest validity regarding the number of days of MVPA against the Global Physical Activity Questionnaire (correlation coefficient 0.53$)$ [30] and accelerometry (0.400.54) $[36,38]$.

Additionally, self-report data on sex, age, height and weight (for body mass index (BMI) calculation), schoolleaving and professional qualification to classify the level of education following the international standard [39], and self-perceived health via the first question of the Minimum European Health Module [40] ("How is your health in general?", response options: "very good"/ "good"/"fair"/"bad"/"very bad", German translation from the German Health Update survey [32]) were asked.

The items of the aforementioned PA questionnaires were mandatory within the online survey to avoid missing values. The additional personal data was voluntary.

\section{Statistical analyses and visualisation}

For the analyses, the sample was limited to the age range of 18-64 years to follow the corresponding target group of the WHO's PA recommendations for 
Table 1 Description of the included measuring instruments, the calculations of the weekly aerobic physical activity, and the comparison with the recommended benchmark

\begin{tabular}{|c|c|c|c|c|c|c|c|c|c|c|}
\hline \# & Questionnaire & $\begin{array}{l}\text { Abbr. } \\
\text { used }\end{array}$ & $\begin{array}{l}\text { Number } \\
\text { of items }\end{array}$ & $\begin{array}{l}\text { Recall } \\
\text { period }\end{array}$ & $\begin{array}{l}\text { Description of } \\
\text { questions }\end{array}$ & $\begin{array}{l}\text { Answer } \\
\text { options }\end{array}$ & $\begin{array}{l}\text { Intensity } \\
\text { description }\end{array}$ & $\begin{array}{l}\text { Minimum } \\
\text { bout } \\
\text { length }\end{array}$ & $\begin{array}{l}\text { Included domains } \\
\text { for the MVPA } \\
\text { recommendations } \\
\text { comparison }\end{array}$ & $\begin{array}{l}\text { Calculation of } \\
\text { MVPA and } \\
\text { comparison } \\
\text { with the } \\
\text { benchmark } \\
\text { ( } \geq 150 \mathrm{~min} / \\
\text { week) }\end{array}$ \\
\hline 1 & $\begin{array}{l}\text { German Health } \\
\text { Interview and } \\
\text { Examination } \\
\text { Survey for } \\
\text { Adults }\end{array}$ & DEGS & 2 & $\begin{array}{l}\text { Typical } \\
\text { week } \\
\text { in the } \\
\text { last } 3 \\
\text { months }\end{array}$ & $\begin{array}{l}\text { 1: number of } \\
\text { days with PA; } \\
\text { 2: average } \\
\text { duration of PA }\end{array}$ & $\begin{array}{l}\text { 1: number or } \\
\text { on no day; } \\
\text { 2: less than } \\
10 \text { min, } 10 \text { to } \\
\text { less than } 30 \\
\text { min, } 30 \text { to } \\
\text { less than } 60 \\
\text { min, more } \\
\text { than } 60 \text { min }\end{array}$ & $\begin{array}{l}\text { Physically } \\
\text { active in a } \\
\text { way that one } \\
\text { sweats or } \\
\text { gets out of } \\
\text { breath }\end{array}$ & $\begin{array}{l}\text { Not } \\
\text { named }\end{array}$ & Not specified & $\begin{array}{l}\text { Number of days } \\
\text { is multiplied by } \\
\text { the mean of the } \\
\text { response } \\
\text { category (the top } \\
\text { category is } \\
\text { estimated at } 60 \\
\text { min) and } \\
\text { compared to the } \\
\text { benchmark }\end{array}$ \\
\hline 2 & $\begin{array}{l}\text { European } \\
\text { Health } \\
\text { Interview } \\
\text { Survey - } \\
\text { Physical } \\
\text { Activity } \\
\text { Questionnaire }\end{array}$ & EHIS & 8 & $\begin{array}{l}\text { Typical } \\
\text { week }\end{array}$ & $\begin{array}{l}\text { (Conservatively, } \\
\text { only items 4-7 } \\
\text { are used for } \\
\text { MVPA calculation } \\
\text { if walking is not } \\
\text { included) } \\
\text { 1: description of } \\
\text { main work; } \\
\text { 2: number of } \\
\text { days with } \\
\text { walking (to get } \\
\text { to and from } \\
\text { places); } \\
\text { 3: average } \\
\text { duration of } \\
\text { walking; } \\
\text { 4: number of } \\
\text { days with } \\
\text { cycling (to get } \\
\text { to and from } \\
\text { places); } \\
\text { 5: average } \\
\text { duration of } \\
\text { cycling; } \\
\text { 6: number of } \\
\text { days with } \\
\text { leisure-time/rec } \\
\text { reational PA } \\
\text { (e.g. brisk walk } \\
\text { ing, ball games, } \\
\text { jogging, cycling, } \\
\text { swimming) } \\
\text { 7: total time of } \\
\text { leisure-time/ } \\
\text { recreational PA } \\
\text { 8: number of } \\
\text { days with } \\
\text { muscle- } \\
\text { strengthening } \\
\text { activities and } \\
\text { exercises } \\
\text { (a) }\end{array}$ & $\begin{array}{l}\text { 4: number } \\
(1-7) \text { or on } \\
\text { no day; } \\
\text { 5: } 10-29 \text { min, } \\
30-59 \text { min, } 1 \\
\text { h to less than } \\
2 \mathrm{~h}, 2 \mathrm{~h} \text { to } \\
\text { less than } 3 \mathrm{~h} \text {, } \\
3 \mathrm{~h} \text { or more } \\
\text { 6: number } \\
\text { (1-7) or on } \\
\text { no day; } \\
\text { 7: total time } \\
\text { in h and min }\end{array}$ & $\begin{array}{l}\text { Physically } \\
\text { active in a } \\
\text { way that } \\
\text { causes at } \\
\text { least a small } \\
\text { increase in } \\
\text { breathing or } \\
\text { heart rate (for } \\
\text { leisure-time/ } \\
\text { recreation) }\end{array}$ & $\begin{array}{l}\text { Only for } \\
\text { cycling (at } \\
\text { least } 10 \\
\text { min) }\end{array}$ & $\begin{array}{l}\text { Leisure-time/ } \\
\text { recreation, } \\
\text { transportation }\end{array}$ & $\begin{array}{l}\text { The number of } \\
\text { days (cycling) is } \\
\text { multiplied by the } \\
\text { mean of the } \\
\text { response } \\
\text { category and } \\
\text { added to total } \\
\text { weekly leisure- } \\
\text { time PA before } \\
\text { the sum is then } \\
\text { compared to the } \\
\text { benchmark }\end{array}$ \\
\hline 3 & Eurobarometer & EURO & 6 & $\begin{array}{l}\text { Last } 7 \\
\text { days }\end{array}$ & $\begin{array}{l}\text { 1: vigorous PA } \\
\text { (e.g. lifting heavy } \\
\text { things, digging, } \\
\text { aerobics, fast } \\
\text { cycling); } \\
\text { 3: moderate PA } \\
\text { (e.g. carrying } \\
\text { light loads, } \\
\text { cycling at normal }\end{array}$ & $\begin{array}{l}\text { 1, 3, and } 5 \text { : } \\
\text { number of } \\
\text { days }(0-7) ; \\
2,4 \text {, and } 6 \text { : } \\
30 \text { min or } \\
\text { less, } 31 \text { to } 60 \\
\text { min, } 61 \text { to } \\
90 \text { min, } 91 \text { to } \\
120 \text { min, }\end{array}$ & $\begin{array}{l}\text { Description is } \\
\text { indirect via } \\
\text { the examples } \\
\text { in the } \\
\text { questions }\end{array}$ & $\begin{array}{l}\text { Only for } \\
\text { walking } \\
\text { (at least } \\
10 \text { min) }\end{array}$ & $\begin{array}{l}\text { Leisure-time/ } \\
\text { recreation, } \\
\text { transportation, } \\
\text { occupational/ } \\
\text { household (via } \\
\text { examples) }\end{array}$ & $\begin{array}{l}\text { Number of days } \\
\text { for each activity } \\
\text { is multiplied by } \\
\text { the mean of the } \\
\text { response } \\
\text { category (the top } \\
\text { category is } \\
\text { estimated at } 120 \\
\text { min) and that for }\end{array}$ \\
\hline
\end{tabular}


Table 1 Description of the included measuring instruments, the calculations of the weekly aerobic physical activity, and the comparison with the recommended benchmark (Continued)

\begin{tabular}{|c|c|c|c|c|c|c|c|c|c|c|}
\hline \# & \multirow[t]{2}{*}{ Questionnaire } & \multirow[t]{2}{*}{$\begin{array}{l}\text { Abbr. } \\
\text { used }\end{array}$} & \multirow[t]{2}{*}{$\begin{array}{l}\text { Number } \\
\text { of items }\end{array}$} & \multirow[t]{2}{*}{$\begin{array}{l}\text { Recall } \\
\text { period }\end{array}$} & $\begin{array}{l}\text { Description of } \\
\text { questions }\end{array}$ & $\begin{array}{l}\text { Answer } \\
\text { options }\end{array}$ & $\begin{array}{l}\text { Intensity } \\
\text { description }\end{array}$ & $\begin{array}{l}\text { Minimum } \\
\text { bout } \\
\text { length }\end{array}$ & $\begin{array}{l}\text { Included domains } \\
\text { for the MVPA } \\
\text { recommendations } \\
\text { comparison }\end{array}$ & $\begin{array}{l}\text { Calculation of } \\
\text { MVPA and } \\
\text { comparison } \\
\text { with the } \\
\text { benchmark } \\
\text { ( } \geq 150 \mathrm{~min} / \\
\text { week) }\end{array}$ \\
\hline & & & & & $\begin{array}{l}\text { pace, doubles } \\
\text { tennis); } \\
5 \text { : walking; } \\
2,4 \text {, and } 6 \text { : } \\
\text { Average duration } \\
\text { of PA }\end{array}$ & $\begin{array}{l}\text { more than } \\
120 \text { min, } \\
\text { never do } \\
\text { [type of } \\
\text { activity] }\end{array}$ & & & & $\begin{array}{l}\text { vigorous activity } \\
\text { is doubled before } \\
\text { all is summed up } \\
\text { and then } \\
\text { compared to the } \\
\text { benchmark }\end{array}$ \\
\hline 4 & $\begin{array}{l}\text { Single-item } \\
\text { measure }\end{array}$ & SIM & 1 & $\begin{array}{l}\text { Past } \\
\text { week }\end{array}$ & $\begin{array}{l}\text { 1: number of } \\
\text { days with at least } \\
30 \text { min PA } \\
\text { (include: sport, } \\
\text { exercise, brisk } \\
\text { walking or } \\
\text { cycling for } \\
\text { recreation or } \\
\text { transport, } \\
\text { exclude: } \\
\text { household- or } \\
\text { job-related) }\end{array}$ & $\begin{array}{l}\text { 1: number of } \\
\text { days }(0-7)\end{array}$ & $\begin{array}{l}\text { Physically } \\
\text { active in a } \\
\text { way that } \\
\text { increases the } \\
\text { breathing } \\
\text { rate }\end{array}$ & $\begin{array}{l}\text { Not } \\
\text { named }\end{array}$ & $\begin{array}{l}\text { Leisure-time/ } \\
\text { recreation, } \\
\text { transportation }\end{array}$ & $\begin{array}{l}\text { Value of } \geq 5 \text { days } \\
\text { means that the } \\
\text { benchmark has } \\
\text { been achieved }\end{array}$ \\
\hline
\end{tabular}

adults [8, 9]. Descriptive analyses were conducted for sex, age, BMI, level of education, and self-perceived health.

For DEGS, EHIS, EURO, and SIM, the volume of weekly MVPA was calculated according to the questionnaire-specific calculations (Table 1) and, based on this, participants were classified concerning whether or not they achieved the WHO's recommendations compared to the benchmark ( $\geq 150 \mathrm{~min} /$ week).

The weekly volume of MVPA according to the four questionnaires was compared via a Friedman test (Dunn-Bonferroni post-hoc tests). Additionally, to visualise the ranges of weekly MVPA, a radar chart was created. Within the diagram, light grey rectangles illustrate all individual values across the four questionnaires, while two black rectangles show the benchmark and - for comparison - the DEGS, EHIS, EURO, and SIM medians.

Cochran's Q was used to determine whether the proportions of participants achieving the WHO's MVPA recommendations differend among the questionnaires (Dunn-Bonferroni post-hoc tests).

Levels of agreement between all possible questionnaire pairs regarding achieving the WHO's MVPA recommendations were evaluated via percent agreement and Kappa statistics with values $\kappa<.60$ indicating inadequate or weak agreement for health-related studies, respectively [41].

Statistical significance was set at $p<.05$. All statistical analyses were run with SPSS 27 (IBM Corp., Armonk, NY, USA).
Finally, using the EHIS data, participants were additionally classified as achieving or not achieving the WHO's MSE recommendations and both recommendations combined.

\section{Results}

\section{Sample description}

During the survey period, the questionnaire was completed 180 times (31.6\% of 569 accesses). Four records were removed due to an age $>64$ years resulting in a total sample of 176 participants (mean age: 33.1 years $(\mathrm{SD}=12.2)$. The majority of the participants were female, highly educated, had a good self-perceived health status, and the mean BMI was in the normal range (Table 2).

\section{Questionnaire comparisons}

The weekly volume of MVPA was lowest for SIM (MED= 90.0, $\mathrm{MIN}=0.0, \mathrm{MAX}=210.0)$ and highest for EURO (MED= 510.0, $\mathrm{MIN}=0.0, \mathrm{MAX}=2430.0)(D E G S: \mathrm{MED}=120.0, \mathrm{MIN}=$ 0.0, $\mathrm{MAX}=420.0$, EHIS: $\mathrm{MED}=240.0, \quad \mathrm{MIN}=0.0, \quad \mathrm{MAX}=$ 1395.0). Differences were statistically significant $\left(X^{2}(3)=\right.$ $346.598, p<.001$ ) in all pairwise comparisons (pairwise DunnBonferroni post-hoc tests $p<.01$ ). The radar chart (Fig. 1) visualises the weekly volume of MVPA according to the four questionnaires compared to the benchmark ( $\geq 150 \mathrm{~min} /$ week). The light grey rectangles illustrate the individual spans of all survey respondents.

The prevalence of participants achieving WHO's MVPA recommendations ranged from SIM 31.3\% (95\% CI 24.5-38.7) to EURO 87.5\% (95\% CI 81.7-92.0) (DEGS 43.2\% (95\% CI 35.8-50.8), EHIS 67.0\% (95\% CI 59.6- 
Table 2 Sample characteristics $(n=176)$

\begin{tabular}{ll}
\hline Characteristic & \\
\hline Sex [female] (n (\%)) & $124(70.5)$ \\
Age [years] (mean (SD)) & $33.1(12.2)$ \\
BMI [kg/m2] (mean (SD)) & $23.4(3.9)$ \\
Level of education ( $(\%))$ & \\
High & $109(62.3)$ \\
Medium & $65(37.1)$ \\
Low & $1(0.6)$ \\
Health status (5=very good, 1=very bad) (mean (SD)) & $4.2(0.7)$ \\
$\quad$ Very good/good (n (\%)) & $145(82.9)$ \\
Fair/bad/very bad (n (\%)) & $30(17.1)$ \\
\hline
\end{tabular}

Note: Valid percentages due to missing data

73.9)) (Fig. 2). Cochran's Q test determined a statistically significant difference in the proportion across the four questionnaires $\left(X^{2}(3)=170.474, p<.001\right)$. Pairwise DunnBonferroni post-hoc tests were statistically significant between all questionnaires $(p<.001)$, except between SIM and DEGS ( $p=.011$, corrected $p=.067)$.

Levels of agreement between all possible questionnaire pairs regarding the classification of respondents as achieving or not achieving the MVPA recommendations were weak (all $\mathrm{K}<0.60$ ) (Table 3 ). The $\mathrm{k}$-values were between 0.10 for EURO and SIM (95\% CI 0.05-0.16) and 0.41 for DEGS and EHIS (95\% CI 0.30-0.53) and DEGS and SIM (95\% CI 0.28-0.55), respectively.

Finally, according to the results of the EHIS and taking into account the item on MSE, $48.9 \%$ of the participants achieved the WHO's MSE recommendations and $42.0 \%$ achieved both recommendations combined.

\section{Discussion}

The present study shows that the questionnaire choice crucially affects the prevalence of recommended PA within the same sample. The prevalence estimates of achieving the WHO's MVPA recommendations ranged from just over $30 \%$ to almost $90 \%$ within the same sample and agreement between the questionnaire pairs regarding the classification of respondents (achieving/ not achieving MVPA recommendations) was weak.

The results are consistent with previous studies finding that different self-reporting measures within the same sample classify survey participants differently in terms of achieving the recommended PA [23, 26, 42]. For example, the study by Steene-Johannessen et al. [26] also used questionnaires that were employed in large surveys yet found substantial discrepancies in the prevalence estimates. Accordingly, such studies and our results suggest that differences in the prevalence estimates of recommended MVPA between studies which use different questionnaires - e.g. in country comparisons [14, $17,18]$ - are not necessarily due to the different PA behaviour of those surveyed, but rather are more likely to be affected by differences in the measuring instruments chosen [43]. In the review by Macniven et al., the prevalence estimates substantially vary - with similar time periods - within eleven of the thirteen countries with more than one survey [18].

It seems obvious that instrument-specific differences in terms of measured activity and the methods used to calculate the achievement of the MVPA recommendations are reasons for the differing prevalence estimates in the present study. Although all included questionnaires could be used to determine the prevalence of recommended

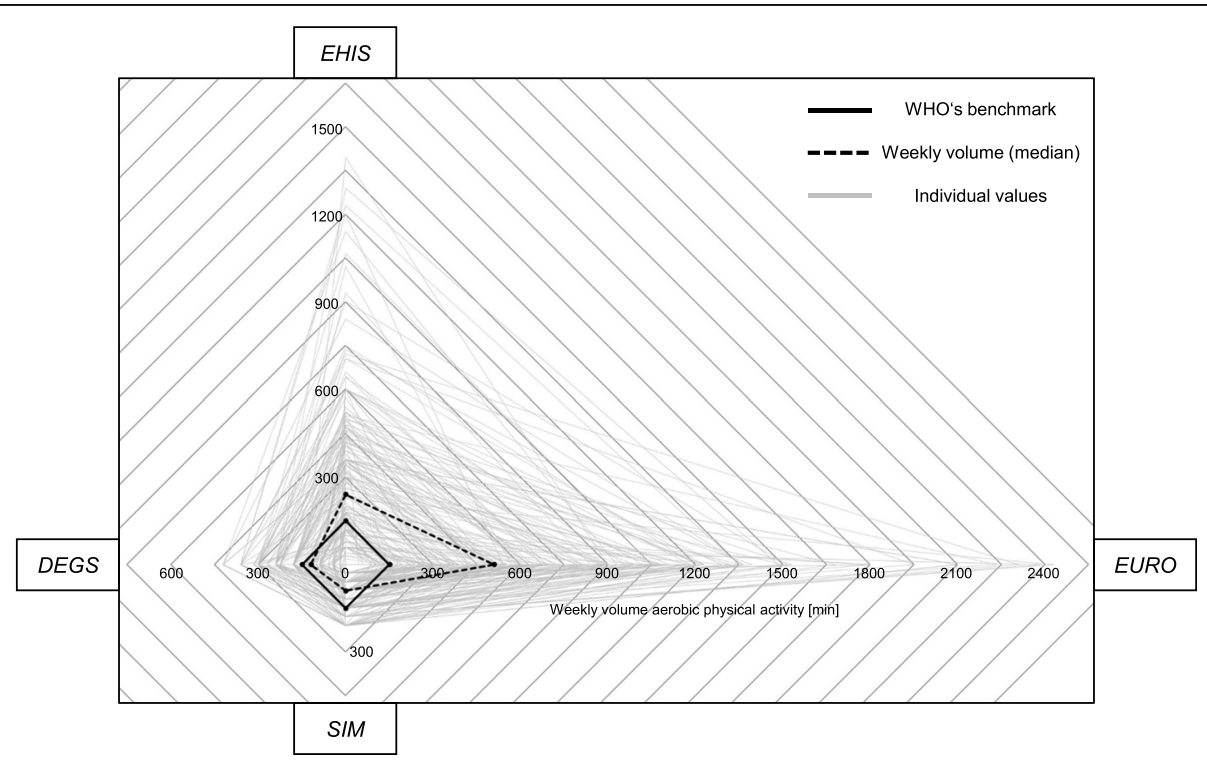

Fig. 1 Weekly volume of aerobic physical activity across the four questionnaires 


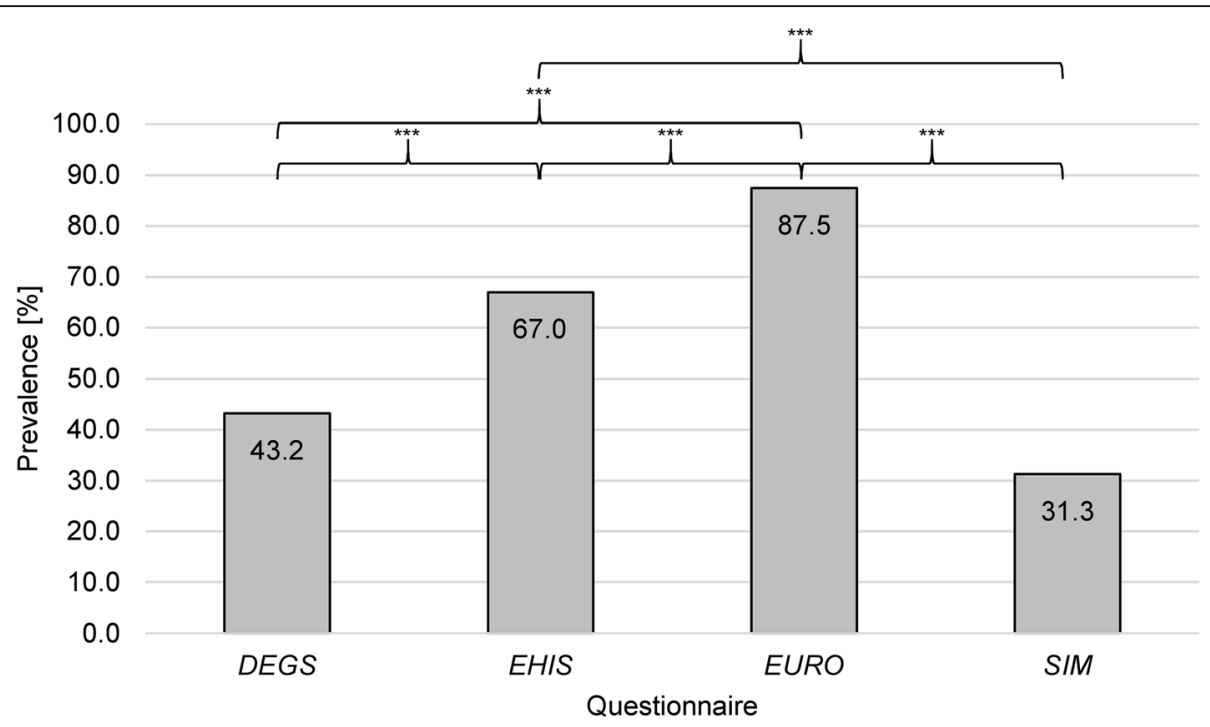

Fig. 2 Prevalence of recommended aerobic physical activity across the four questionnaires

MVPA, they more or less substantially differ in terms of intensity descriptions, the activities surveyed, recall periods, and minimum bouts of MVPA. Moreover, the respective calculations of weekly aerobic PA are based on frequencies, total durations or combinations of both. Even if surveys refer to comparable activity recommendations, differences in instrument design seem to lead to different prevalence estimates per se.

Beyond that, it might even be necessary to investigate how collected data should be analysed and to more fundamentally investigate what kind of PA should be measured in order to accurately survey health-enhancing PA. A study by Mealing et al., e.g., has already shown that the use of different scoring algorithms alone (frequency, duration, volume) leads to substantial variations in the estimation regarding the prevalence of recommended MVPA [44]. In its new recommendations for 2020 [9] compared to the recommendations for 2010 [8], the WHO recently removed the requirement of at least 10-min bouts of PA, thus focusing only on the weekly volume. But in addtion, although all domains are essentially mentioned in the WHO's PA recommendations (leisure-time/recreation, transportation, occupational/household) $[8,9]$ to reach the recommended weekly volume, there is currently further discussion in research about the extent to which PA is beneficial to health regardless of the setting, or whether a distinction should be made between leisure-time and transport PA and work-related activity [45-48]. It is self-explanatory that the methodological decision to (not) measure certain domain-specific PA has a significant impact on the prevalence of recommended PA [18]. This indicates that questionnaires need to be further adapted to be up to date with the evolving PA recommendations [49] and also with possible new research findings.

Independent of discussions on PA benchmarks for health $[45,50]$, consideration may need to be given to the standardisation of PA measures in surveillance of the achievement of PA recommendations [14, 17, 18]. Strain et al. concluded in a recent narrative review that due to different PA surveillance measures in the home countries of the United Kingdom, the extent to which PA recommendations are met, currently cannot be compared across the countries [43]. Although there are already efforts to use the same questionnaire in several countries (e.g. World Health Survey [51], International Prevalence Study on Physical Activity [52], or WHO STEPwise approach), the limited comparability of the instruments means that such multi-country data cannot be juxtaposed. Moreover, a convincing argument against methodological standardisation is that it may require the interruption of trend data that is relevant e.g. from a political perspective [43]. However, a study by Carlson et al. showed not only cross-sectional differences between three surveillance systems in the United States, but also slightly different physical activity trends over several years of observation [53], which questions the added value of parallel longitudinal studies carried out with different instruments. Therefore, in order to provide comparable, valid and reliable PA data, harmonised monitoring systems need to be implemented, which is the objective of the EUPASMOS project [54], for example. Another potential approach would be to harmonise data to a compatible format using indirect models (via bridge equations and intermediate values) [55]. The goal of comparable prevalence estimates - regardless of 


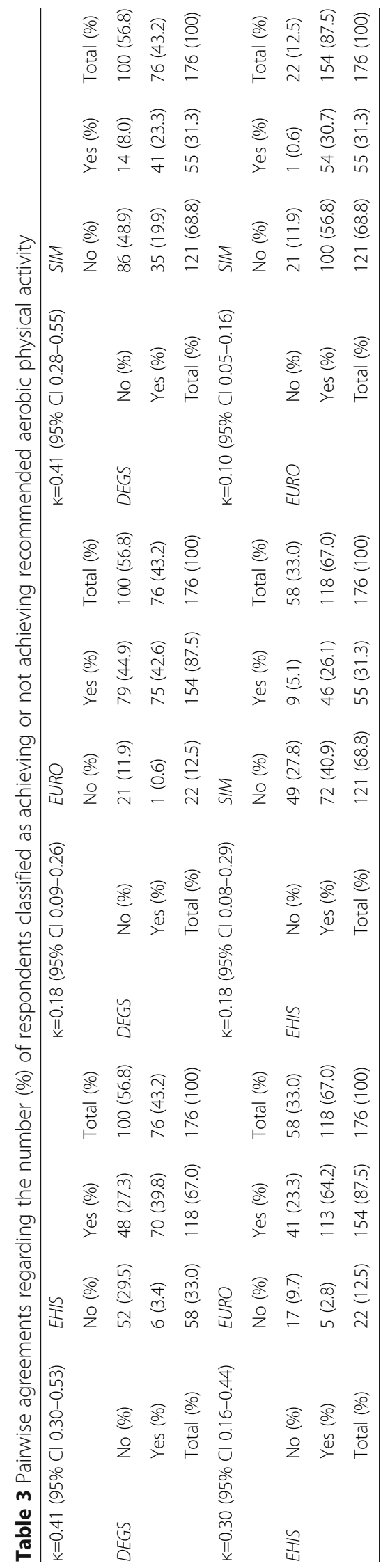


the instrument used and only depending on the PA behaviour of the persons investigated - should be further pursued to create a reliable data basis for PA promotion strategies.

An additional option to reduce uncertainties regarding the comparability of multiple surveys, should be objective measuring instruments. Without question, PA questionnaires are practical and economical for population-based surveys [56, 57], but they still tend to be inaccurate compared to objective instruments, such as accelerometers or pedometers [58-60], and they rarely show good results in terms of both reliability and validity [33, 61]. Moreover, regarding the classification of persons in terms of achieving the MVPA recommendations, self-reports show low or moderate sensitivity compared to objective measurement methods and low levels of agreement [26, 42]. Consequently, the potential and utility of integrating device-based measures into PA surveillance or a combination of objective and subjective measurement methods should be considered to validly and reliably survey the (WHO's) whole PA recommendations [26, 43, 62-64].

Notwithstanding the challenges of a comparable MVPA surveillance, another crucial gap remains, as MSE recommendations have only been integrated in a few PA surveillance studies to date $[65,66]$, which is why Strain et al. accordingly called them "forgotten guidelines" [67]. MSE offer multiple health benefits such as improved physical performance and functional independence, and it assists in the prevention and management of numerous health complaints and diseases [68-71]. Furthermore, scientific findings emphasise the independent positive effects of MSE and that achieving the MSE recommendations appears to be at least as important as adherence to the MVPA recommendations in terms of reducing mortality risk [72, 73]. In addition, the prevalence for achieving both the WHO's PA recommendations combined seems to be constantly lower than for MVPA alone (some examples: Australia: 53\% for MVPA, 19\% for MSE, and 15\% for both combined [74]; Finland: $31 \%$ for MVPA, $17 \%$ for MSE, and $11 \%$ for both [75]; Germany: 45\% for MVPA, 29\% for MSE, and $22 \%$ for both [20]). Due to MSE's strong relevance from a public health perspective [70], researchers should therefore choose a survey method that reflects both recommendations and the measurement of MSE should be included in population surveys [43], although MSE can currently be exclusively assessed by selfreport and not device-based [65]. Alternatively, study authors should at least distinguish accurately between MVPA and MSE when reporting the prevalence of recommended PA.

The bottom line of the present study is that the measurement of recommended PA strongly depends on the questionnaire itself (the inclusion of different types of
PA and the corresponding calculation method). Even if differences in instrument design and analysis methods may be sources of the wide variability, all instruments included in this study indicate that they could be used to survey the prevalence of people achieving the WHO's MVPA recommendations. However, there is limited interchangeability and prevalence widely varies within the same sample.

\section{Strengths and limitations}

The main strength of the study is that it is a comparison of established PA questionnaires within the same sample with a direct link to the WHO's PA recommendations, thus providing an important contribution to the discussion on PA surveillance and being highly relevant for future political measures in terms of reducing the prevalence of insufficient PA. Three of the four measuring instruments have already been used in recent years within national and international surveys $[19,20,22]$.

For the $D E G S$, no information on reliability and validity could be found from the RKI [19] and for the SIM, the German version [36] an established instrument [30] was slighty rephrased. However, the aim of the present study was not to use instruments that are most valid, but rather to compare the influence of the choice of instruments on the prevalence estimates. For this purpose, we used instruments that were frequently used in population-based surveys as well as the SIM, which can very simply survey the achievement of PA recommendations.

Due to the recruitment strategy (online channels of the German Sport University Cologne and publication on SurveyCircle), it is likely that mainly younger, educated and health-oriented people accessed the online survey. However, due to the homogeneity of this positive sample, it could be assumed that the chance of correctly answered questionnaires was increased [76-79]. Future studies with more heterogeneous samples could consider the influence of different variables (e.g. educational level or age) or aim for a comparable measurement method comparison in specific subgroups (e.g. very active athletes or inactive persons).

\section{Conclusions}

At present, data on the prevalence of recommended PA - if collected through a questionnaire - must be viewed sceptically against the background of the measuring instrument used. Our study underlines the need for standardised survey and analysis methods in PA surveillance within and between countries [14, 18, 43], and efforts should be undertaken to harmonise monitoring systems accordingly. Especially at the individual level, the intermethod differences can be very large and the agreement 
weak, meaning that the results are not necessarily interchangeable $[26,42,80]$.

As a solid basis for political measures to reduce physical inactivity, accurately-collected and comparable data is needed and it should not be the choice of one questionnaire or another that determines whether the prevalence of recommended PA is low or high, but rather the actual PA behaviour of those surveyed.

\section{Abbreviations}

Abbr: Abbreviation; BMI: Body mass index; CDC: Centers for Disease Control and Prevention; Cl: Confidence interval; DEGS: Physical activity-related questions of the German Health Interview and Examination Survey for Adults; EHIS: European Health Interview Survey Physical Activity Questionnaire; EURO: Physical activity-related questions of the Eurobarometer survey; h: Hours; MAX: Maximum; MED: Median; MIN: Minimum; min: Minutes; MSE: Muscle-strengthening activities and exercises; MVPA: Moderate- and vigorous-intensity activity; PA: Physical activity; RKI: Robert Koch Institute; SD: Standard deviation; SIM: Single-item measure; WHO: World Health Organization

\section{Acknowledgements}

The authors thank Marilena Werth and Sabine Maas (Public Relations and Communication, German Sport University Cologne) for their support in data collection.

\section{Authors' contributions}

Conceptualization, G.S. and K.R.; Formal analysis, G.S. and M.G.; Investigation: G.S. and M.G.; Methodology, G.S., K.R. and A.S.; Project administration, G.S.; Resources, A.S.; Supervision, A.T. and A.S.; Visualization, G.S. and M.G., Writing - Original Draft, G.S. and M.G.; Writing - Review \& Editing, K.R., A.T. and A.S. All authors read and approved the final manuscript.

\section{Funding}

The authors received no specific funding for this work. Open Access funding enabled and organized by Projekt DEAL.

\section{Availability of data and materials}

The datasets used and analysed during the current study are available from the corresponding author on reasonable request.

\section{Ethics approval and consent to participate}

The Ethics Committee of the German Sport University Cologne (reference: 127/2019) approved the study. Informed consent was given (via check box) prior to the beginning of the online survey.

\section{Consent for publication}

Not applicable.

\section{Competing interests}

The authors declare that they have no competing interests.

\footnotetext{
Author details

${ }^{1}$ Working Group Physical Activity-Related Prevention Research, Institute of Movement Therapy and Movement-Oriented Prevention and Rehabilitation, German Sport University Cologne, Am Sportpark Müngersdorf 6, 50933 Cologne, Germany. ${ }^{2}$ Department of Movement-Oriented Prevention and Rehabilitation Sciences, Institute of Movement Therapy and Movement-Oriented Prevention and Rehabilitation, German Sport University Cologne, Am Sportpark Müngersdorf 6, 50933 Cologne, Germany. ${ }^{3}$ Institute of Sports Science, Eberhard Karls University Tübingen, Wilhelmstraße 124, 72074 Tübingen, Germany. ${ }^{4}$ Interfaculty Research Institute for Sport and Physical Activity, Eberhard Karls University Tübingen, Wilhelmstraße 124, 72074 Tübingen, Germany.
}

Received: 4 August 2020 Accepted: 21 December 2020

Published online: 07 January 2021

\section{References}

1. Warburton DER, Bredin SSD. Health benefits of physical activity: a systematic review of current systematic reviews. Curr Opin Cardiol. 2017;32:541-56. https://doi.org/10.1097/HCO.0000000000000437.

2. Penedo FJ, Dahn JR. Exercise and well-being: a review of mental and physical health benefits associated with physical activity. Curr Opin Psychiatry. 2005;18:189-93. https://doi.org/10.1097/00001504-20050300000013.

3. Reiner M, Niermann C, Jekauc D, Woll A. Long-term health benefits of physical activity--a systematic review of longitudinal studies. BMC Public Health. 2013;13:813. https://doi.org/10.1186/1471-2458-13-813.

4. Pedersen BK, Saltin B. Exercise as medicine - evidence for prescribing exercise as therapy in 26 different chronic diseases. Scand J Med Sci Sports. 2015;25(Suppl 3):1-72. https://doi.org/10.1111/sms.12581.

5. Lee I-M, Shiroma EJ, Lobelo F, Puska P, Blair SN, Katzmarzyk PT. Effect of physical inactivity on major non-communicable diseases worldwide: an analysis of burden of disease and life expectancy. Lancet. 2012;380:219-29. https://doi.org/10.1016/S0140-6736(12)61031-9.

6. World Health Organization. Global status report on noncommunicable diseases 2014. Geneva: World Health Organization; 2014.

7. Ding D, Lawson KD, Kolbe-Alexander TL, Finkelstein EA, Katzmarzyk PT, van Mechelen W, Pratt M. The economic burden of physical inactivity: a global analysis of major non-communicable diseases. Lancet. 2016;388:1311-24. https://doi.org/10.1016/S01406736(16)30383-X.

8. World Health Organization. Global recommendations on physical activity and health promotion. Geneva: World Health Organization; 2010.

9. World Health Organization. WHO guidelines on physical activity and sedentary behaviour. Geneva: World Health Organization; 2020.

10. Davies SC, Atherton F, McBride M, Calderwood C. UK chief medical Officers' physical activity guidelines; 2019.

11. U.S. Department of Health and Human Services. Physical Activity Guidelines for Americans, 2nd ed. Washington, DC: U.S. Department of Health and Human Services; 201.

12. Brown WJ, Bauman A, Bull FC, Burton N. Development of evidence-based physical activity recommendations for adults (18-64 years): report prepared for the Australian Government Department of Health; 2012.

13. Rütten A, Pfeifer K. Nationale Empfehlungen für Bewegung und Bewegungsförderung; 2016.

14. Hallal PC, Andersen LB, Bull FC, Guthold R, Haskell W, Ekelund U. Global physical activity levels: surveillance progress, pitfalls, and prospects. Lancet. 2012;380:247-57. https://doi.org/10.1016/50140-6736(12)60646-1.

15. Guthold R, Stevens GA, Riley LM, Bull FC. Worldwide trends in insufficient physical activity from 2001 to 2016: a pooled analysis of 358 populationbased surveys with 1.9 million participants. Lancet Glob Health. 2018;6: e1077-86. https://doi.org/10.1016/S2214-109X(18)30357-7.

16. World Health Organization. More active people for a healthier world: global action plan on physical activity 2018-2030. Geneva: World Health Organization; 2018.

17. Loyen A, van Hecke L, Verloigne M, Hendriksen I, Lakerveld J, SteeneJohannessen J, et al. Variation in population levels of physical activity in European adults according to cross-European studies: a systematic literature review within DEDIPAC. Int J Behav Nutr Phys Act. 2016;13:72. https://doi. org/10.1186/s12966-016-0398-2.

18. Macniven R, Bauman A, Abouzeid M. A review of population-based prevalence studies of physical activity in adults in the Asia-Pacific region. BMC Public Health. 2012;12:41. https://doi.org/10.1186/14712458-12-41

19. Krug S, Jordan S, Mensink GBM, Müters S, Finger J, Lampert T. Physical activity: results of the German health interview and examination survey for adults (DEGS1): English version of "Körperliche Aktivität. Ergebnisse der Studie zur Gesundheit Erwachsener in Deutschland (DEGS1)". Bundesgesundheitsbl Gesundheitsforsch Gesundheitsschutz. 2013;56:76571. https://doi.org/10.1007/s00103-012-1661-6.

20. Finger JD, Mensink GBM, Lange C, Manz K. Health-enhancing physical activity during leisure time among adults in Germany. J Health Monitor. 2017;2:37-44. https://doi.org/10.17886/RKI-GBE-2017-040. 
21. Wallmann-Sperlich B, Froboese I. Physical activity during work, transport and leisure in Germany--prevalence and socio-demographic correlates. PLoS One. 2014;9:e112333. https://doi.org/10.1371/journal.pone.0112333.

22. Gerovasili V, Agaku IT, Vardavas Cl, Filippidis FT. Levels of physical activity among adults 18-64 years old in 28 European countries. Prev Med. 2015;81: 87-91. https://doi.org/10.1016/j.ypmed.2015.08.005.

23. Sarkin JA, Nichols JF, Sallis JF, Calfas KJ. Self-report measures and scoring protocols affect prevalence estimates of meeting physical activity guidelines. Med Sci Sports Exerc. 2000;32:149-56. https://doi.org/10.1097/ 00005768-200001000-00022.

24. American College of Sports Medicine position stand. The recommended quantity and quality of exercise for developing and maintaining cardiorespiratory and muscular fitness in healthy adults. Med Sci Sports Exerc. 1990;22:265-74.

25. Pate RR, Pratt M, Blair SN, Haskell WL, Macera CA, Bouchard C, et al. Physical activity and public health. A recommendation from the Centers for Disease Control and Prevention and the American College of Sports Medicine. JAMA. 1995;273:402-7. https://doi.org/10.1001/jama.273.5.402.

26. Steene-Johannessen J, Anderssen SA, van der Ploeg HP, Hendriksen IJM, Donnelly AE, Brage S, Ekelund U. Are self-report measures able to define individuals as physically active or inactive? Med Sci Sports Exerc. 2016;48: 235-44. https://doi.org/10.1249/MSS.0000000000000760.

27. Scheidt-Nave C, Kamtsiuris P, Gößwald A, Hölling H, Lange M, Busch MA et al. German health interview and examination survey for adults (DEGS) design, objectives and implementation of the first data collection wave. BMC Public Health. 2012;12:730. https://doi.org/10.1186/1471-2458-12-730.

28. Finger JD, Tafforeau J, Gisle L, Oja L, Ziese T, Thelen J, et al. Development of the European health interview survey - physical activity questionnaire (EHISPAQ) to monitor physical activity in the European Union. Arch Public Health. 2015;73:59. https://doi.org/10.1186/s13690-015-0110-z.

29. European Commission. Eurobarometer 80.2 (2013) 2017: GESIS Data Archive: ZA5877 Data file Version 2.0.0, TNS Opinion. Brussels. . https://doi.org/10. 4232/1.12792.

30. Milton K, Bull FC, Bauman A. Reliability and validity testing of a single-item physical activity measure. Br J Sports Med. 2011;45:203-8. https://doi.org/10. 1136/bjsm.2009.068395.

31. Baumeister SE, Ricci C, Kohler S, Fischer B, Töpfer C, Finger JD, Leitzmann MF. Physical activity surveillance in the European Union: reliability and validity of the European health interview survey-physical activity questionnaire (EHIS-PAQ). Int J Behav Nutr Phys Act. 2016;13:61. https://doi. org/10.1186/s12966-016-0386-6

32. Robert Koch-Institut. Fragebogen zur Studie "Gesundheit in Deutschland aktuell" GEDA 2014/2015-EHIS. J Health Monitor. 2017;2:105-35. https://doi. org/10.17886/RKI-GBE-2017-014

33. van Poppel MNM, Chinapaw MJM, Mokkink LB, van Mechelen W, Terwee CB. Physical activity questionnaires for adults: a systematic review of measurement properties. Sports Med. 2010;40:565-600. https://doi.org/10. 2165/11531930-000000000-00000.

34. Craig $C L$, Marshall AL, Sjöström M, Bauman AE, Booth ML, Ainsworth BE, et al. International physical activity questionnaire: 12-country reliability and validity. Med Sci Sports Exerc. 2003;35:1381-95. https://doi.org/10.1249/01. MSS.0000078924.61453.FB.

35. Lee PH, Macfarlane DJ, Lam TH, Stewart SM. Validity of the International Physical Activity Questionnaire Short Form (IPAQ-SF): a systematic review. Int J Behav Nutr Phys Act. 2011;8:115. https://doi.org/10.1186/1479-5868-8-115.

36. Wanner M, Probst-Hensch N, Kriemler S, Meier F, Bauman A, Martin BW. What physical activity surveillance needs: validity of a single-item questionnaire. Br J Sports Med. 2014;48:1570-6. https://doi.org/10.1136/ bjsports-2012-092122.

37. Department of Health. Be active, Be Healthy: A plan for getting the nation moving. London: Department of Health; 2009.

38. Milton K, Clemes S, Bull F. Can a single question provide an accurate measure of physical activity? Br J Sports Med. 2013;47:44-8. https://doi.org/ 10.1136/bjsports-2011-090899.

39. UNESCO Institute for Statistics. International standard classification of education: ISCED 2011. Montreal: UNESCO-UIS; 2012.

40. European Health Expectancy Monitoring Unit. The Minimum European Health Module. EHEMU Technical report 2010; 2010.

41. McHugh ML. Interrater reliability: the kappa statistic. Biochem Med. 2012 276-82. https://doi.org/10.11613/BM.2012.031.
42. Hukkanen H, Husu P, Sievänen H, Tokola K, Vähä-Ypyä H, Valkeinen H, et al. Aerobic physical activity assessed with accelerometer, diary, questionnaire, and interview in a Finnish population sample. Scand J Med Sci Sports. 2018; 28:2196-206. https://doi.org/10.1111/sms.13244.

43. Strain T, Milton K, Dall P, Standage M, Mutrie N. How are we measuring physical activity and sedentary behaviour in the four home nations of the UK? A narrative review of current surveillance measures and future directions. Br J Sports Med. 2019. https://doi.org/10.1136/bjsports-2018-100355.

44. Mealing NM, Bowles HR, Merom D, Bauman A. Impact of scoring algorithm on physical activity prevalence estimates in Australian adults. J Sci Med Sport. 2011;14:27-32. https://doi.org/10.1016/j.jsams.2010.05.003.

45. de Souto Barreto P. Time to challenge public health guidelines on physical activity. Sports Med. 2015;45:769-73. https:/doi.org/10.1007/s40279-015-0326-7.

46. Holtermann A, Hansen JV, Burr H, Søgaard K, Sjøgaard G. The health paradox of occupational and leisure-time physical activity. Br J Sports Med. 2012:46:291-5. https://doi.org/10.1136/bjsm.2010.079582.

47. Holtermann A, Krause N, van der Beek AJ, Straker L. The physical activity paradox: six reasons why occupational physical activity (OPA) does not confer the cardiovascular health benefits that leisure time physical activity does. Br J Sports Med. 2018;52:149-50. https://doi.org/10.1136/bjsports2017-097965.

48. Carré F. Physical activity as the cure-all, is it always true? Eur J Prev Cardiol. 2019;26:1874-6. https://doi.org/10.1177/2047487319862068.

49. Troiano RP, Stamatakis E, Bull FC. How can global physical activity surveillance adapt to evolving physical activity guidelines? Needs, challenges and future directions. Br J Sports Med. 2020;54:1468-73. https:// doi.org/10.1136/bjsports-2020-102621.

50. Warburton DER, Bredin SSD. Reflections on physical activity and health: what should we recommend? Can J Cardiol. 2016;32:495-504. https://doi. org/10.1016/j.cjca.2016.01.024.

51. Guthold R, Ono T, Strong KL, Chatterii S, Morabia A. Worldwide variability in physical inactivity. Am J Prev Med. 2008;34:486-94. https://doi.org/10.1016/j. amepre.2008.02.013.

52. Bauman A, Bull F, Chey T, Craig CL, Ainsworth BE, Sallis JF, et al. The International Prevalence Study on Physical Activity: results from 20 countries. Int J Behav Nutr Phys Act. 2009;6:21. https://doi.org/10.1186/14795868-6-21.

53. Carlson SA, Densmore D, Fulton JE, Yore MM, Kohl HW. Differences in Physical Activity Prevalence and Trends from 3 U.S. Surveillance Systems: NHIS, NHANES, and BRFSS. J Physical Activity and Health. 2009;6:S18-27. https://doi.org/10.1123/jpah.6.s1.s18.

54. EUPASMOS. European Union Physical Activity and Sport Monitoring System. 2020. https://eupasmos.com/. Accessed 2 Dec 2020.

55. Pearce M, Bishop TRP, Sharp S, Westgate K, Venables M, Wareham NJ, Brage S. Network harmonization of physical activity variables through indirect validation. J Measurement Phys Behav. 2020;3:8-18. https://doi.org/10.1123/ impb.2019-0001.

56. Sallis JF, Saelens BE. Assessment of physical activity by self-report: status, limitations, and future directions. Res Q Exerc Sport. 2000;71(Suppl 2):1-14. https://doi.org/10.1080/02701367.2000.11082780

57. Ara I, Aparicio-Ugarriza R, Morales-Barco D, Nascimento de Souza W, Mata E, González-Gross M. Physical activity assessment in the general population; validated self-report methods. Nutr Hosp. 2015;31(Suppl 3):211-8. https:// doi.org/10.3305/nh.2015.31.sup3.8768.

58. Shephard RJ. Limits to the measurement of habitual physical activity by questionnaires. Br J Sports Med. 2003;37:197-206; discussion 206. https://doi. org/10.1136/bjsm.37.3.197.

59. Skender S, Ose J, Chang-Claude J, Paskow M, Brühmann B, Siegel EM, et al. Accelerometry and physical activity questionnaires - a systematic review. BMC Public Health. 2016;16:515. https://doi.org/10.1186/s12889-016-3172-0.

60. Dowd KP, Szeklicki R, Minetto MA, Murphy MH, Polito A, Ghigo E, et al. A systematic literature review of reviews on techniques for physical activity measurement in adults: a DEDIPAC study. Int J Behav Nutr Phys Act. 2018; 15:15. https://doi.org/10.1186/s12966-017-0636-2.

61. Helmerhorst HJF, Brage S, Warren J, Besson H, Ekelund U. A systematic review of reliability and objective criterion-related validity of physical activity questionnaires. Int J Behav Nutr Phys Act. 2012;9:103. https://doi.org/10. 1186/1479-5868-9-103.

62. Brühmann BA, Schmidt ME, Steindorf K. Assessment of physical activity in epidemiological studies: are questionnaires obsolete in the era of accelerometry? 2014. https://doi.org/10.3205/mibe000155. 
63. Lee I-M, Shiroma EJ. Using accelerometers to measure physical activity in large-scale epidemiological studies: issues and challenges. Br J Sports Med. 2014;48:197-201. https://doi.org/10.1136/bjsports-2013-093154.

64. Loyen A, Clarke-Cornwell AM, Anderssen SA, Hagströmer M, Sardinha LB, Sundquist $K$, et al. Sedentary time and physical activity surveillance through accelerometer pooling in four European countries. Sports Med. 2017:47: 1421-35. https://doi.org/10.1007/s40279-016-0658-y.

65. Bennie JA, Shakespear-Druery J, de Cocker K. Muscle-strengthening Exercise Epidemiology: a New Frontier in Chronic Disease Prevention. Sports Med Open. 2020. https://doi.org/10.1186/s40798-020-00271-w.

66. Milton K, Varela AR, Strain T, Cavill N, Foster C, Mutrie N. A review of globa surveillance on the muscle strengthening and balance elements of physical activity recommendations. JFSF. 2018;03:114-24. https://doi.org/10.22540/ JFSF-03-114

67. Strain T, Fitzsimons C, Kelly P, Mutrie N. The forgotten guidelines: crosssectional analysis of participation in muscle strengthening and balance \& co-ordination activities by adults and older adults in Scotland. BMC Public Health. 2016;16:1108. https://doi.org/10.1186/s12889-016-3774-6.

68. Westcott WL. Resistance training is medicine: effects of strength training on health. Curr Sports Med Rep. 2012;11:209-16. https://doi.org/10.1249/JSR. Ob013e31825dabb8.

69. Hart PD, Buck DJ. The effect of resistance training on health-related quality of life in older adults: Systematic review and meta-analysis. Health Promot Perspect. 2019;9:1-12. https://doi.org/10.15171/hpp.2019.01.

70. Volaklis KA, Halle M, Meisinger C. Muscular strength as a strong predictor of mortality: a narrative review. Eur J Intern Med. 2015;26:303-10. https://doi. org/10.1016/j.ejim.2015.04.013.

71. Abramowitz MK, Hall CB, Amodu A, Sharma D, Androga L, Hawkins M. Muscle mass, BMI, and mortality among adults in the United States: a population-based cohort study. PLoS One. 2018;13:e0194697. https://doi. org/10.1371/journal.pone.0194697.

72. Stamatakis E, Lee I-M, Bennie J, Freeston J, Hamer M, O'Donovan G, et al. Does strength-promoting exercise confer unique health benefits? A pooled analysis of data on 11 population cohorts with all-cause, Cancer, and cardiovascular mortality endpoints. Am J Epidemiol. 2018;187:1102-12. https://doi.org/10.1093/aje/kwx345

73. FitzGerald SJ, Barlow CE, Kampert JB, Morrow JR, Jackson AW, Blair SN. Muscular fitness and all-cause mortality: prospective observations. J Phys Act Health. 2004;1:7-18. https://doi.org/10.1123/jpah.1.1.7.

74. Bennie JA, Pedisic Z, van Uffelen JGZ, Gale J, Banting LK, Vergeer I, et al. The descriptive epidemiology of total physical activity, muscle-strengthening exercises and sedentary behaviour among Australian adults--results from the National Nutrition and physical activity survey. BMC Public Health. 2016; 16:73. https://doi.org/10.1186/s12889-016-2736-3.

75. Bennie JA, Pedisic Z, Suni JH, Tokola K, Husu P, Biddle SJH, Vasankari T. Selfreported health-enhancing physical activity recommendation adherence among 64,380 finnish adults. Scand J Med Sci Sports. 2017;27:1842-53. https://doi.org/10.1111/sms.12863.

76. Vandelanotte C, Duncan MJ, Stanton R, Rosenkranz RR, Caperchione CM, Rebar AL, et al. Validity and responsiveness to change of the active Australia survey according to gender, age, BMI, education, and physical activity level and awareness. BMC Public Health. 2019;19:407. https://doi.org/10.1186/ s12889-019-6717-1.

77. Winckers ANE, Mackenbach JD, Compernolle S, Nicolaou M, van der Ploeg HP, Bourdeaudhuij de I, et al. Educational differences in the validity of selfreported physical activity. BMC Public Health 2015;15:1299. doi:https://doi. org/10.1186/s12889-015-2656-7.

78. Howitt C, Brage S, Hambleton IR, Westgate $K$, Samuels TA, Rose AM, Unwin N. A cross-sectional study of physical activity and sedentary behaviours in a Caribbean population: combining objective and questionnaire data to guide future interventions. BMC Public Health. 2016;16:1036. https://doi.org/ 10.1186/s12889-016-3689-2
79. Matthews CE, Moore SC, George SM, Sampson J, Bowles HR. Improving selfreports of active and sedentary behaviors in large epidemiologic studies. Exerc Sport Sci Rev. 2012;40:118-26. https://doi.org/10.1097/JES. Ob013e31825b34a0

80. Colley RC, Butler G, Garriguet D, Prince SA, Roberts KC. Comparison of selfreported and accelerometer-measured physical activity in Canadian adults. Health Rep. 2018;29:3-15.

\section{Publisher's Note}

Springer Nature remains neutral with regard to jurisdictional claims in published maps and institutional affiliations.
Ready to submit your research? Choose BMC and benefit from:

- fast, convenient online submission

- thorough peer review by experienced researchers in your field

- rapid publication on acceptance

- support for research data, including large and complex data types

- gold Open Access which fosters wider collaboration and increased citations

- maximum visibility for your research: over $100 \mathrm{M}$ website views per year

At BMC, research is always in progress.

Learn more biomedcentral.com/submissions 